\title{
PRIMARY AND SECONDARY KINETOPROPHYLAXY OF CIFOSIS AT PUPILS
}

\author{
Florian Benedek ${ }^{1,}$ Elena Vizitiu ${ }^{2}$ \\ 1,2 University ”Ștefan cel Mare” from Suceava, street „Universității No.13”, Suceava, România
}

\begin{abstract}
We chose this theme important nowadays because we want to interfere with the development of specific programmes pupils aged between 12 and 13 years to have a posture correct biomechanical point of view. Scientific article is made on a sample of 20 subjects, and the kinetoprophylaxy program includes 3 stages of 12 means for all the muscles of the back. The period during which the program has been conducted January-April 2019, two weekly sessions of 50 minutes. We believe the school is kinetic prophylaxies cifosis indispensable, even more students tend to sit leaning because of vicious positions from the bench and the engineer that is weighted with fractious, following a physical therapist should be present in any school to prevent physical deficiencies.

Angle cifosis appears in conditions that destroying one or more vertebral bodies leading to a consolidation.

„Arched" cifosis appears in the conditions affecting the spine on a larger expanse.
\end{abstract}

Keywords: kinetoprophylaxy, cifosis, means, students

\section{Introduction}

We believe that the role and importance of physical deficiencies at students kinetoprophylaxy is easily understood by teachers of physical education and sport that can occur with specific means and methods of physical education.

According to studies of a. Ignatius, and d. Moțet, cifosies are deviations of the spine in the anteroposterior plane, with the convexity of the curve facing backwards. Cifosies are divided into two categories: functional and pathological. Cifosis attitude is the most common deviation of the spine and is an exaggeration of the physiological curvature that can extend into the upper cervical, lumbar region below or on the entire spinal column. This curvature is most frequently encountered at school during the period of growth. Most of the times a cifosis attitude is due to the inadequacy of the back muscles, which don't have the force required for the maintenance of the torso $[1,3]$

Working table with too low or too high seat, static activity extended through physical exercises and unmatched, strenuous physical work and lack of education to contribute to the maintenance of roadholding fair kyphosis attitude. [4]

In this regard, and other specialists in the books that they have written "functional Reeducation into diseases of the spine" holds that bolding is cifosis a physiological curvature in the thoracic region. You can calculate use a plumb with one thread on the back of adolescent; when touching the tip of the dorsal curvature is found towards the thorny apophysis $\mathrm{C} 7$ vertebra, at more than 3 cm away. Finally after Dr. Clement B, cifosis is characterized as being the most common deviation of the spine, driven by a rise in the dorsal curvature. Clinically, we distinguish two types of cifosis: angular (with small radius of curvature) and arched cifosis (with radius of curvature).

Cifosis angle appears in conditions that destroying one or more vertebral bodies which is leading to a settlement of these.

Arched cifosis appears in the conditions affecting the spine on a larger expanse. 
Pathologic cifosis can be installed by emphasizing physiological either by „deletion” of cifosis of a physiological lordosis. Cifosis means, the attitude or deformity in which the backbone take the most convenient position, in order to improve pain, known that vertebral ligament and the front of the column are most richly innervated. [1]

Dorsal cifosis, means an emphasis of functional cifosis, bolding physiological rachis adapting to changes of anatomical elements in order to mitigate the painful syndrome. Is the most common deviation of the spine, often being associated with many pathological conditions. [2,5]

We believe that the best principles, rules and methods for preventing physical deficiencies is based on the analysis of students ' life in the family and at school. The student must receive and understand information permanently to prevent deficiencies that may appear due to the vicious positions of spine. Prophylaxis of spinal attitudes can also be done by means of swimming.[6]

\section{Methods}

In this study we started from the following assumptions:

$>\quad$ It is assumed that through the use of funds from physical therapy improves health and fighting vicious positions.

$>\quad$ It is assumed that through the use of funds from physical therapy may prevent cifosis attitude.

\section{THE PURPOSE}

The aim of this study was the development of a kinetoprophylaxy program that lead to the recovery of the spine, taking account both of the dorsal column that has a cifosis attitude and need to be rescued and the other cervical and lumbar curves, which are posture correctly so as not to accentuate them during kinetic.

\section{GOALS AND OBJECTIVES:}

1. Optimization of morph-functionals through the implementation of the programme of kinetoprophylaxy;

2. Informing students of the benefits of this program;

The materials we used were: mattress, sticks, balls, etc.

The place in which the research was conducted, at secondary school „Ion Creanga" from Suceava and the physical therapy room. The program took place from January until April. We have done two sessions per week.

The research has passed the following stages:

- $\quad$ The first stage was held that theoretical documentation consisted of studying the material from literature;

- $\quad$ In the second stage we met with patients and we have prepared the material for testing and treatment;

- $\quad$ In the third step we have developed and we applied the means and techniques of physical therapy program;

- In the final stage we appreciated developments in dynamic parameters, we processed graphically the data obtained, followed by an interpretation. we have made these meetings to prevent cifosis, subjects are in seventh grade.

\begin{tabular}{|c|c|c|}
\hline \multicolumn{3}{|c|}{ Prevention programme for cifosis } \\
\hline \multicolumn{3}{|l|}{ Objects } \\
\hline \multicolumn{3}{|c|}{$\begin{array}{l}\text { To maintain the correct attitude and equilibrium } \\
\text { Increase joint mobility } \\
\text { Toning muscles }\end{array}$} \\
\hline \multirow[t]{3}{*}{ Stage I } & Content & dosage $-20 \mathrm{~min}$ \\
\hline & $\begin{array}{l}\text { standing with legs far sitting, with arms outstretched-arm and } \\
\text { torso extension performing up }\end{array}$ & \\
\hline & Fandat from sitting forward with hands to your basin, arms and & \\
\hline
\end{tabular}




\begin{tabular}{|c|c|c|}
\hline & torso with extension capability top & \\
\hline & $\begin{array}{l}\text { with the legs sitting far from the front of fixed scale, hands grabs } \\
\text { one stick, carrying forward with the torso, extension basin at left } \\
\text { foot, then right }\end{array}$ & \\
\hline & Walk from the peaks up to three steps torso extension & \\
\hline & Away with hands on hips lunge pushing forward basin & \\
\hline & $\begin{array}{l}\text { Running with the legs swings back with the hands behind the } \\
\text { neck }\end{array}$ & \\
\hline \multirow[t]{7}{*}{ Stage II } & Content & dosage $-35 \mathrm{~min}$ \\
\hline & $\begin{array}{l}\text { From supine, with legs bent and arms stretched sideways, go their } \\
\text { separate ways knees to chest and return to starting position }\end{array}$ & \\
\hline & $\begin{array}{l}\text { From prone, raising his head and torso, upper limb position by } \\
\text { changing it to grade the effort (in addition to the body, under the } \\
\text { Chin, neck, shoulders) }\end{array}$ & \\
\hline & $\begin{array}{l}\text { From position "on his knees" with a walking stick in his hands } \\
\text { full recovery of the torso, extension arms and maintaining the } \\
\text { position for a few seconds of maximum extension }\end{array}$ & \\
\hline & $\begin{array}{l}\text { Ample inspiration, prolonged exhalation. It inspires, the student } \\
\text { movement of manually controlling the chest; It is deep, prolonged } \\
\text { lapses with the contraction of the abdominal muscles and } \\
\text { retracted }\end{array}$ & \\
\hline & $\begin{array}{l}\text { Maintaining your spine with wearing a book on your head. } \\
\text { Outreach: keeping the book on their heads, perform exercises: } \\
\text { extension on peaks and lower limb half flexion }\end{array}$ & \\
\hline & $\begin{array}{l}\text { Walk with breathing, leading hands through lowering the top } \\
\text { and after let them by the side }\end{array}$ & \\
\hline \multirow[t]{7}{*}{ Stage III } & Content & dosage $-50 \mathrm{~min}$ \\
\hline & $\begin{array}{l}\text { Walk from the narrow side of the gymnastics bank, with the } \\
\text { introduction of arms through before, obliquely upward, at each } \\
\text { step get lower your arms }\end{array}$ & \\
\hline & $\begin{array}{l}\text { Walk from the peaks with a ball head on medicinal supported } \\
\text { by hands, torso extension at each step at the same time }\end{array}$ & \\
\hline & Running back leg swing & \\
\hline & $\begin{array}{l}\text { On his knees, carrying the arms through upper-torso before } \\
\text { twisting to the left with the right hand touching the left heel, } \\
\text { right arm up diagonally, the same exercise on the opposite side }\end{array}$ & \\
\hline & $\begin{array}{l}\text { Lying with his hands under his chin, facial, leg extension } \\
\text { capability,comeback with his feet on the ground }\end{array}$ & \\
\hline & $\begin{array}{l}\text { Lying down, arms and torso extension before, with the raising } \\
\text { of the ground }\end{array}$ & \\
\hline
\end{tabular}

\section{ASSESSMENT TESTS:}

For the testing of 20 students have used the following tests:

1. Ott Test

2. Stibor Test

3. Index fingers-ground

4. Articular balance

5. Muscular balance

\section{Results and Discussions}

Pursuant to those assessment tests 20 subjects, it was found that 2 subjects exhibit physical scoliosis and 1 presents cifo-lordosis. For the three subjects in the sample chose we recommend to go to the doctor, and then to follow a program of recovery through shifts both on land and in water. Other subjects have only cifosis attitude following the prevention program 4 months. 
Each table represents a statistical indicator for evaluating the arithmetic average value of the group got into the study.[7]

Table no. 1 Tests for assessment of the spine

\begin{tabular}{|l|l|l|l|l|}
\hline \multicolumn{2}{|l|}{ Ott Test } & Stibor Test & $\begin{array}{l}\text { Index fingers- } \\
\text { ground }\end{array}$ & $\begin{array}{l}\text { The perimeter of } \\
\text { the thorax }\end{array}$ \\
\hline Initially & $35 \mathrm{~cm}$ & $44 \mathrm{~cm}$ & $20 \mathrm{~cm}$ & $\begin{array}{l}\text { Inspire 84; } \\
\text { Expire 79 }\end{array}$ \\
\hline Intermediate & $37 \mathrm{~cm}$ & $49 \mathrm{~cm}$ & $17 \mathrm{~cm}$ & $\begin{array}{l}\text { Inspire 85; Expire } \\
80\end{array}$ \\
\hline Final & $38 \mathrm{~cm}$ & $54 \mathrm{~cm}$ & $15 \mathrm{~cm}$ & $\begin{array}{l}\text { Inspire 86; } \\
\text { Expire 81 }\end{array}$ \\
\hline
\end{tabular}

As can be seen from the table above the arithmetic shows a significant improvement in the four tests applied on the group. Even if values indicates a significant improvement in the recovery programme should be continued for an optimal maintenance of the spine.

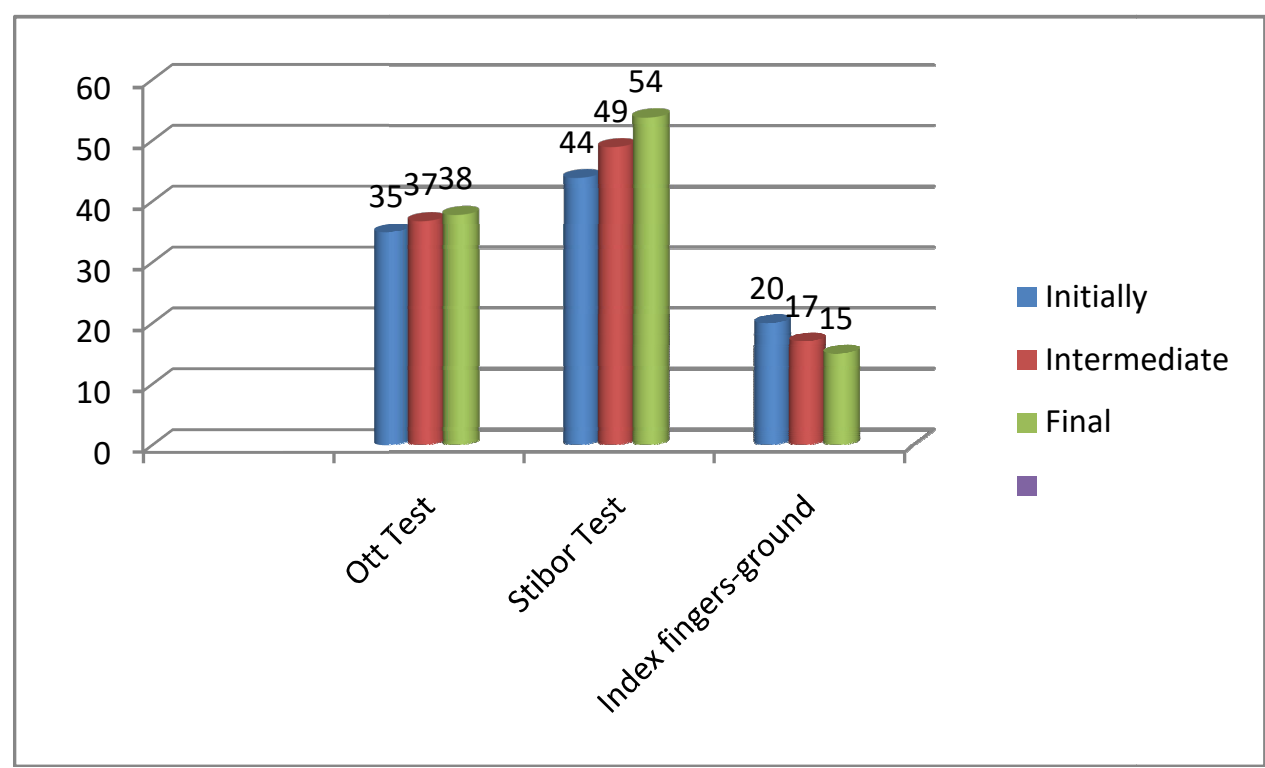

Figure 1.Evaluation of spine chart

Table 2 Balance of the articular dorso-lumbar

\begin{tabular}{|c|c|c|c|c|}
\hline \multicolumn{2}{|l|}{ Torso flexion } & \multirow{2}{*}{$\begin{array}{l}\begin{array}{l}\text { Torso } \\
\text { extension }\end{array} \\
20 \mathrm{~cm}\end{array}$} & \multirow{2}{*}{$\begin{array}{l}\text { The inclination of } \\
\text { the torso } \\
22 \mathrm{~cm}\end{array}$} & \multirow{2}{*}{$\begin{array}{l}\text { Torso rotation } \\
32 \mathrm{~cm}\end{array}$} \\
\hline Initially & $85 \mathrm{~cm}$ & & & \\
\hline Intermediate & $87 \mathrm{~cm}$ & $26 \mathrm{~cm}$ & $31 \mathrm{~cm}$ & $39 \mathrm{~cm}$ \\
\hline Final & $90 \mathrm{~cm}$ & $30 \mathrm{~cm}$ & $35 \mathrm{~cm}$ & $44 \mathrm{~cm}$ \\
\hline
\end{tabular}

In the table no. 2 articular balance is presented of the lumbar spine with four tests applied statistical indicator representing the arithmetic mean of the group. As to the notice stand originally to the final there is an improvement in values, meaning that the proposed new exercises were effective. 


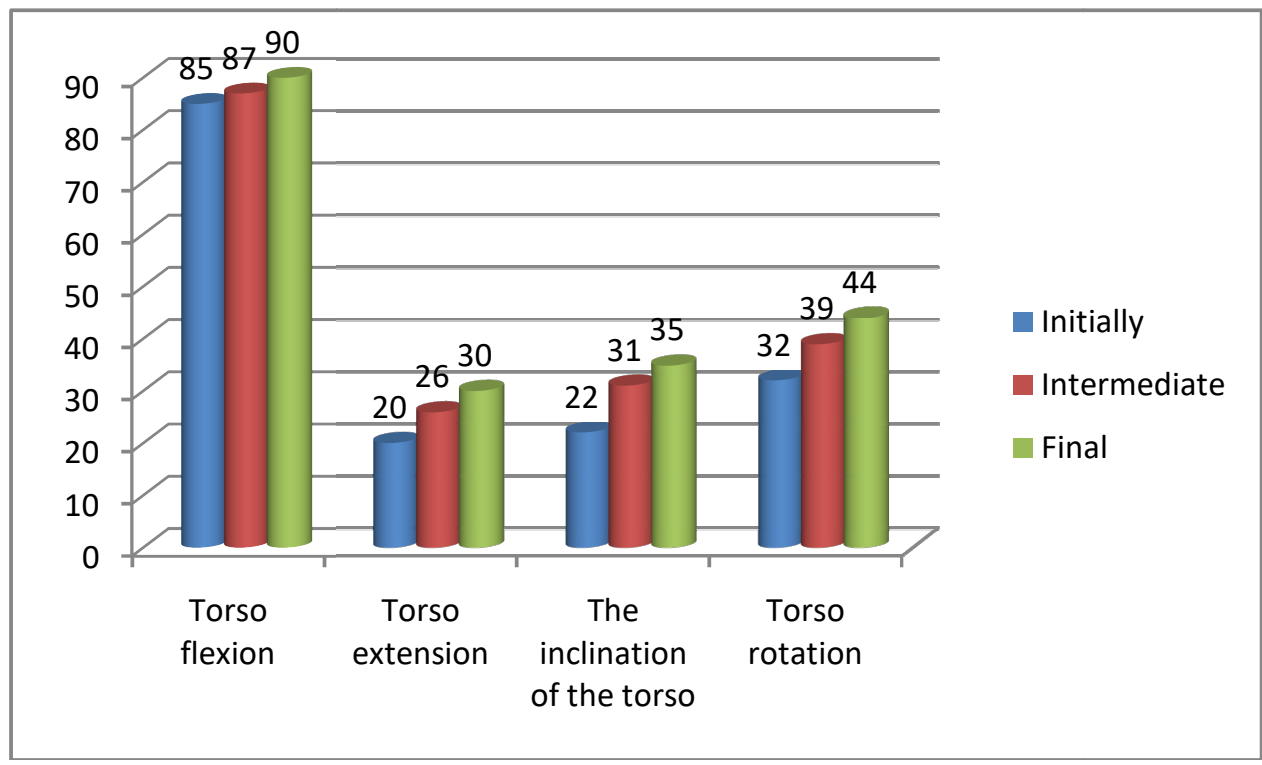

Figure 2 The articular balance of the joint of the dorso-lumbar

Table 3 balance sheet of muscle of the dorso-lumbar

\begin{tabular}{|l|l|l|l|l|}
\hline \multicolumn{2}{|c|}{ Muscular balance column dorso-lumbar } \\
\hline & $\begin{array}{l}\text { Torso } \\
\text { flexio } \\
\mathrm{n}\end{array}$ & Torso extension & $\begin{array}{l}\text { The inclination of } \\
\text { the torso }\end{array}$ & Torso rotation \\
\hline Initially & F4+ & F4+ & F4 & F4 \\
\hline Final & F5 & F5 & F5 & F5 \\
\hline
\end{tabular}

To fully assess we used Muscular balance column dorso-lumbar on this group. It has pursued the muscular force, and the evaluation it was found an increase in force in the end.

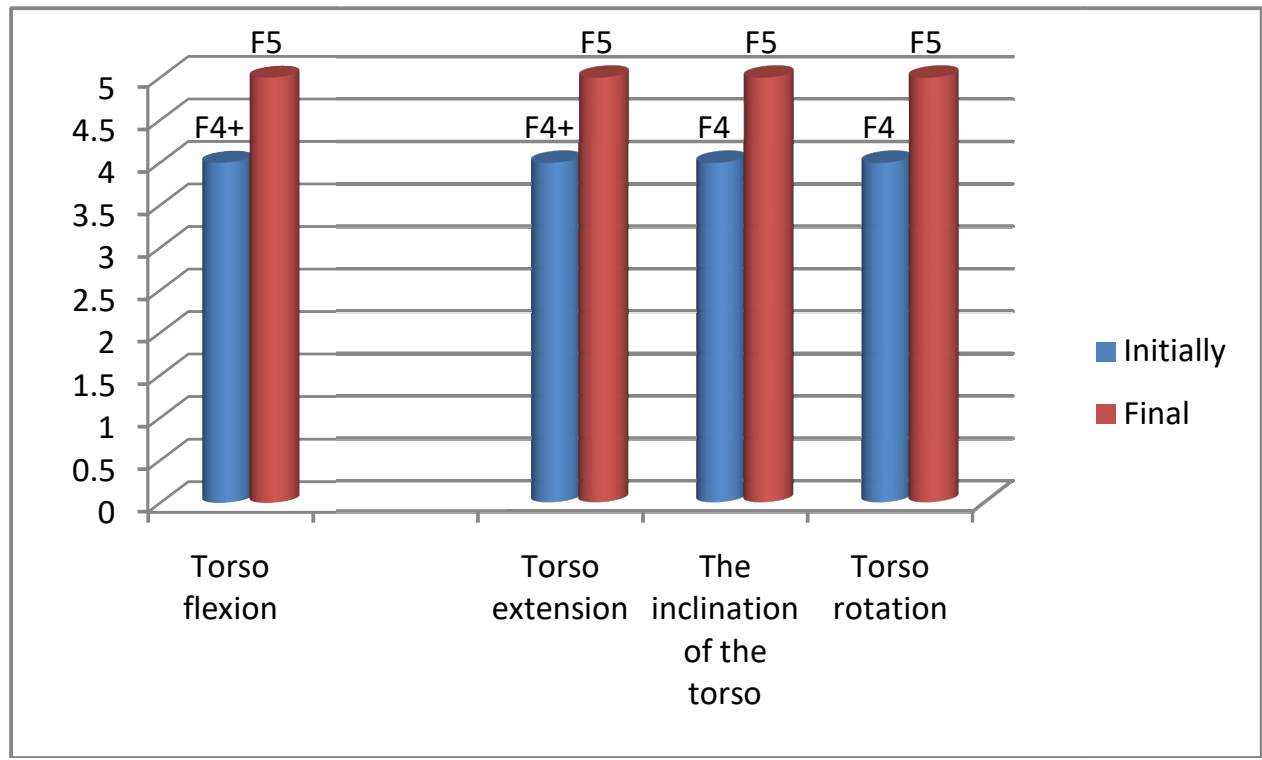

Figure 3. Muscular balance of dorso-lumbar spine 
After these meetings of kinetoprophylaxies, subjects feel better, tests on values that we've applied at first grew, the Ott $3 \mathrm{~cm}, 10 \mathrm{~cm}$ Stibor Test, index fingers ground decreased by $5 \mathrm{~cm}$ and chest perimeter increased by $5 \mathrm{~cm}$.

This chapter is the most important in the paper, aiming to detail and prove the statements made in the previous chapters. With this purpose in mind, tables and figures can be used to support the information, and add more clarity to the demonstration.

Tables

All tables should be numbered with Arabic numerals. Headings should be placed above tables, underlined and centred. Leave one line space between the heading and the table. Only horizontal lines should be used within a table, to distinguish the column headings from the body of the table. Tables must be embedded into the text and not supplied separately.

\section{Conclusions}

As an overall conclusion we can say that through the application of a kinetoprophylaxy program on subjects with cifosis attitude have obtained good results. The first action should be undertaken in the prevention of physical deficiencies, particularly of cifosis, is that of education and improving the skill of proper attitude of the body in children.

As a result of the study underline once again that the attitude of cifosis can be prevented in the school, as part of physical education classes by using physical corrective exercises.

Physical exercises in our program were conducted in static and dynamic anatomical and physiological limits of the body.

\section{Bibliography}

1. Baciu Clement, (1974),,Aparatul locomotor”. Editura Stadion, București;

2. Bălteanu Veronica (1999) - "Profilaxia şi terapia deficienţelor fizice în şcoală". Editura Univ. "Al.I. Cuza” Iaşi,;

3. Dumitru Dumitru (1984) - „Reeducarea funcțională în afecțiunile coloanei vertebrale”. Editura Sport-Turism, Bucureşti,;

4. Ionescu A., Moțet D. (1984) - „Corectarea deficiențelor fizice la copii de vârstă școlară”. Editura Didactică şi Pedagogică, Bucureşti,;

5. Păun Radu, Șuteanu Ștefan (1999) - „Tratat de medicină internă vol II”. Editura medicală, București;

6. Raţă Elena, (2014) - Teoria şi practica în sporturi de apă: înot, Editura Didactică şi Pedagogică, Bucureşti, ISBN 978-973-30-3656-2,

7. Sbenghe T (1987) - „Kinetologie profilactică, terapeutică şi de recuperare”, Editura Medicală, Bucureşti; 